\title{
Feargal Cochrane
}

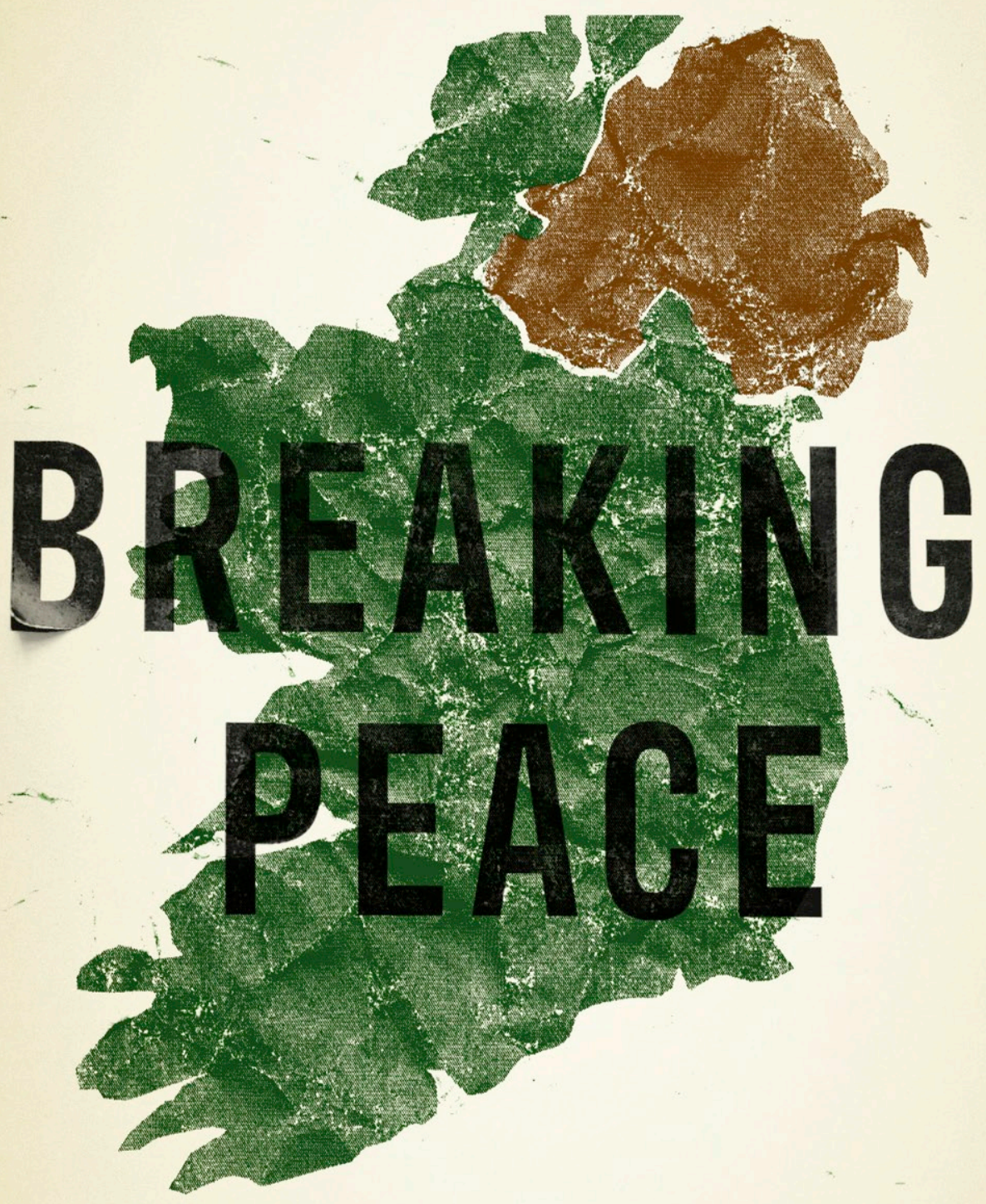

\section{Brexit and Northern Ireland}




\section{Breaking peace}

\section{MANCHESTER 1824}

Manchester University Press 
Feargal Cochrane - 9781526142566

Downloaded from manchesterhive.com at 04/26/2023 11:36:10AM 


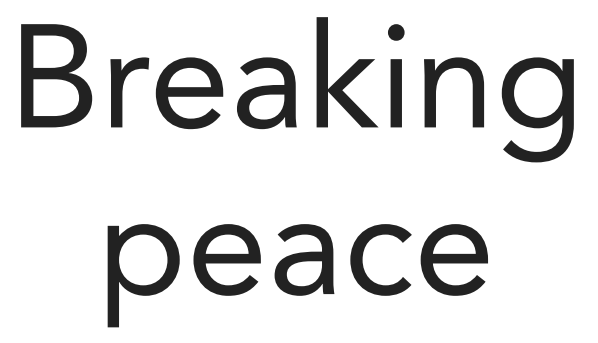

\section{Brexit and Northern Ireland}

Feargal Cochrane

Manchester University Press 
Copyright (C) Feargal Cochrane 2020

The right of Feargal Cochrane to be identified as the author of this work has been asserted by him in accordance with the Copyright, Designs and Patents Act I988.

Published by Manchester University Press

Altrincham Street, Manchester Mi 7JA

www.manchesteruniversitypress.co.uk

British Library Cataloguing-in-Publication Data

A catalogue record for this book is available from the British Library

ISBN 978 I 526I 42559 hardback

First published 2020

The publisher has no responsibility for the persistence or accuracy of URLs for any external or third-party internet websites referred to in this book, and does not guarantee that any content on such websites is, or will remain, accurate or appropriate.

Cover: Rob Pinney

Typeset

by New Best-set Typesetters Ltd 